\title{
THE CONTINUING TRADITION OF AUSTRONESIAN CULTURE AT LIMA PULUH KOTO, WEST SUMATERA ${ }^{1}$
}

\author{
TRADISI BERLANJUT BUDAYA AUSTRONESIA \\ DI LIMA PULUH KOTO, SUMATERA BARAT
}

\author{
Rr. Triwurjani \\ Pusat Penelitan Arkeologi Nasional \\ demplon1@yahoo.com
}

\begin{abstract}
ABSTRAK
Diaspora Austronesia menunjukkan kurang lebih 60\% penutur tinggal di Indonesia. Salah satu lokasi jejak Austronesia adalah di Kabupaten Lima Puluh Koto, Sumatera Barat, yaitu sebaran menhir yang mencapai ratusan jumlahnya. Bentuk budaya Austronesia dikenal sebagai budaya yang meneruskan tradisi-tradisi masa prasejarah dan berlanjut pada masa sejarah, seperti tradisi megalitik. Permasalahannya adalah, apabila budaya megalitik dibawa oleh para migran, pada periode Austronesia protosejarah ataukah Austronesia masa kini menhir-menhir tersebut berada?, bagaimana pola sebaran menhir-menhir tersebut? dan siapa pendukungnya?. Penelitian ini berusaha mengungkapkan bentuk dan persebaran budaya megalitik dan migrasi Austronesia di Kawasan Lima Puluh Koto. Maksud dan tujuan penelitian ini adalah untuk mengungkapkan sejarah kebudayaan dan adaptasi kaum migran dalam perpekstif diaspora Austronesia, sehingga memperkaya informasi tentang diaspora Austronesia dan asal-usul etnogenesis bangsa Indoensia. Hasil penelitian yang dilakukan dengan metode kualitatif ini menunjukkan bahwa tradisi megalitik di kawasan Lima Puluh Koto adalah sebaran menhir yang membentuk kelompok-kelompok berdasarkan nagari pada area tertentu. Sebaran menhir ini selain mempunyai fungsi sakral juga mempunyai fungsi profan antara lain sebagai batas kampung, batas halaman, maupun batas jalan raya desa, atau jalan-jalan di kampung.
\end{abstract}

Kata Kunci: Diaspora, Austronesia, Megalitik, Menhir, Tradisi.

\begin{abstract}
Austronesian diaspora shows that around $60 \%$ of Austronesian-speaking people live in Indonesia. Among the locations with traces of Austronesian cultural remains is the information about the diaspora of Research reveals that the continuing megalithic tradition. The problem is: if megalithic culture was brought by migrants in which Austronesian period did the menhirs should be placed, the proto-historic or recent Austronesian; how is the dispersal pattern of the menhirs; and who were the bearers of the culture. Therefore we have to reveal the form and dispersal of the megalithic culture and Austronesian migration in Lima Puluh Koto Area. The aim of this research is revealing cultural history through the migrant's adaptation within the perspective of Austronesian diaspora. Thus information about the diaspora of the Austronesians and the ethnogenesis of Indoneisan nation can be recognized. Research reveals that the continuing megalithic tradition which is used the qualitative method and assumed base on archaeological remains at Lima Puluh Koto area is a distribution of menhirs, that forms clusters in accordance with nagari (state) at certain area, and they are dispersed up to the hilly area. Some of these menhirs have sacred function but there are also those with profane functions like marks of village, house yard, or street boundaries, as well as the marker of village or hamlet roads.
\end{abstract}

Keywords: Diaspora, Austronesia, Megalithic, Menhir, Tradition.

Tanggal masuk : 31 Juli 2016

Tanggal diterima : 31 Oktober 2016

${ }^{1}$ Artikel ini pernah dibawakan dalam bentuk powerpoint pada Seminar Internasional Diaspora Austronesia di Bali pada Bulan Juli 2016. 


\section{INTRODUCTION}

Talking about the national from other disciplines of science can be used to bridge and solve the problems regarding the Austronesians. Archaeological studies about

According to Harry Truman Simanjuntak, a prehistoric archaeologist, based on the period and material culture the study on Austronesian diaspora can be divided into three categories: 1) Prehistoric Austronesia Prasejarah (around 2000 BP) with its Neolithic culture; 2) Proto-historic Austronesia (around $2000 \mathrm{BP}$ to the $4^{\text {th }}-5^{\text {th }}$ centuries $A D$, which is characterized by burial culture, jar burial, burial with grave goods, metal culture (Dongson), and Megalithic culture; and 3) Recent Austronesia, since the Indonesian independence until now, and is characterized by national culture that show that Indonesia has been free from foreign culture (Simanjuntak, 2010: 42).

There are a number of theories proposed by scholars regarding the diaspora, including Out of Taiwan and Out of Africa. The Out of Taiwan theory believes that the Austronesian speakers came from Taiwan, while the Out of Africa theory states that they came from Africa. Both assert that in reality, the Austronesian-speaking people have existed and lived in Indonesia for a long time.

The theory that the Austronesian speakers were originated from Taiwan and migrated to Indonesia was proposed by Robert Blust and Peter Bellwood. Robert Blust is a linguist who studied the Austronesia Language Family based on the distribution of the languages and concludes that Taiwan is the place of origin of the Austronesian speakers (Blust 1984, 1985: 45-68). 
On the other hand, Peter Bellwood, a prehistoric archaeologist specialized in Southeast Asia, states that the Austronesian speakers came from Taiwan and the coastal area of Southern China (Bellwood, 1995:97-98). This statement is based on researches on artifacts and their environment, and the distribution of adzes and pottery. The migration of the Austronesian speakers did not happen at once but in several stages (Bellwood, 2000). in Nusa Tenggara and the North coast of West Papua. The language used is the language of ProtoMalayo-Polynesian (PCMP); Stage $V$, occurred in 2500 BC with migration from Northern Papua to the west, which developed South Halmahera-West Nugini languages (SHWNG). There was also migration eastwards to Oceania up to Bismarck Islands in around 1500 BC. Some of the Austronesian speakers who reached Java and

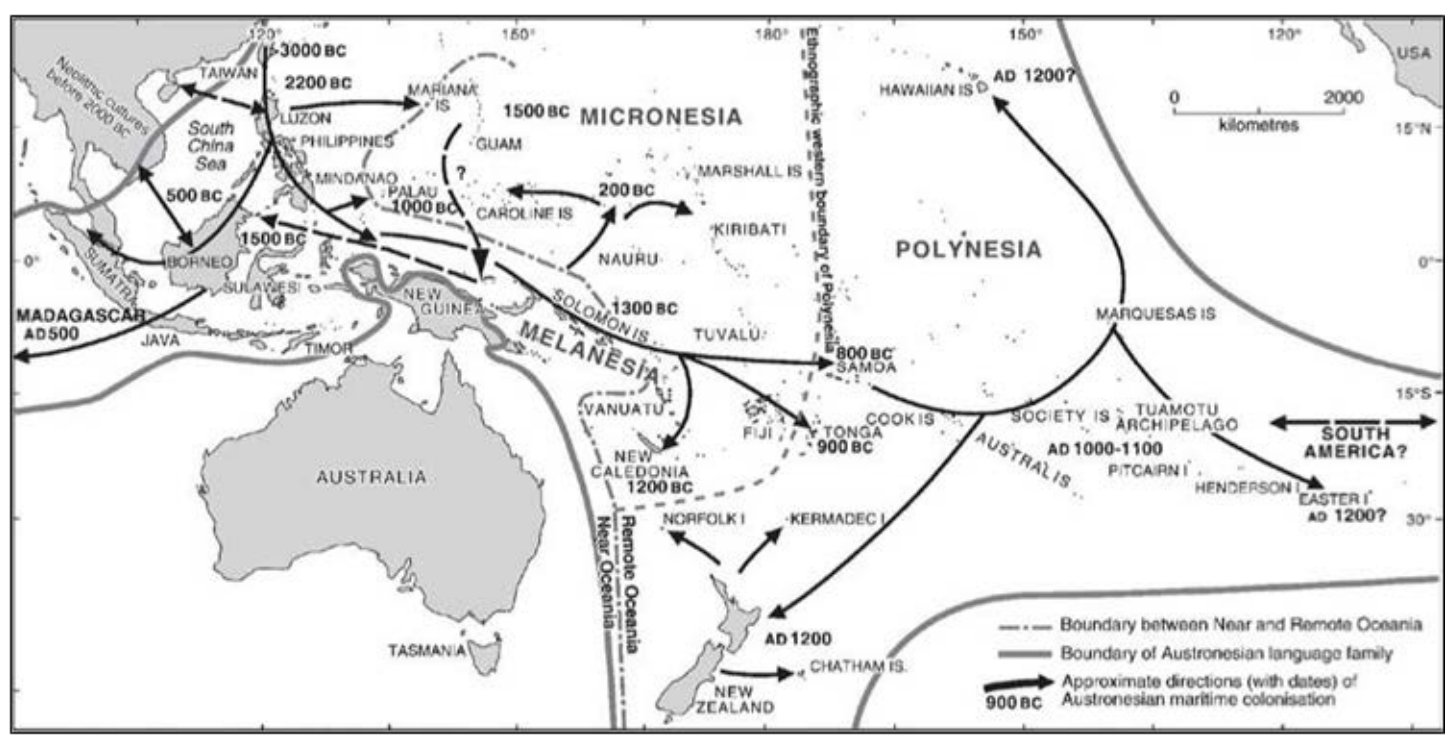

Figure 1. Distribution of Austronesia Language Family. Source: Bellwood, 2012: S363-S378

There are five stages of the journey, among others: Stage I (5000 - 4000 BC), which was the migration of a group of farmers from South China to Taiwan, where they had not spoken Austronesian languages; Stage II (around 4500 3000 BC) from Taiwan to the Philippines, where they developed Proto-Malayo-Polynesian language; Stage III (3500 BC - before 2000 $\mathrm{BC})$, where they developed West Proto Malayo-Polynesia (PWMP) and Central-Eastern Proto MalayoPolynesia PCEMP); Stage IV (3000 $B C$ or $2000 \mathrm{BC}$ ), migration from North Maluku to the south and east
Sumatera then migrated to the Malaysian Peninsula and Vietnam around 500 BC. Some of the Austronesian speakers in Kalimantan sailed up to Madagascar in the same period (Tanudirdjo \& Bagyo Prasetyo, 2005: 77-96).

The two opinions have similarities and are often quoted by scholars although there is still a probability of new opinions regarding this Out of Taiwan mode, due to new data. In this case, Sumatera Island clearly belongs to Austronesian language family and was an integral part of the destinations of Austronesian speakers. 
Some traces of Austronesian on the island of Sumatera have been previously investigated, they are Megalithic Site of Pasemah (Bagyo Prasetyo et al., 2009; Kristantina Indriastuti, 2001); the Megalithic Statues of Pasemah (Triwurjani, 2015); Megalithic site of Kerinci (Bonatz, 2009; Fadhila A. A, 2010); Primary burial at Harimau Cave, Padang Bindu (Truman Simanjuntak, 2004), North coast of Central Java (Gunadi Kasnowiharjo, 2013); and Anak Dalam ethnic group in Jambi (Retno Handini, 2005). There is an assumption that Lima Puluh Koto area also traces Austronesian culture, as shown menhirs distributed in every district within the regency. Hundreds of menhirs were found in groups or as individual object, both on plains and hills. If the Megalithic culture was brought by the migrants, there is a question in the Austronesian studies about whether they were originated from proto-historic Austronesia period or recent Austronesian period like the phasing of Austronesian inhabitation in the Indonesian Archipelago ${ }^{3}$ (Simanjuntak, 2010: 41-62).

These menhirs have certain patterns in terms of arrangement, shapes, and decorations. In the scope of Austronesian Diaspora study, the megalithic culture was introduced by the migrants, problem discussed is what is the period the menhirs proto-historic or recent Austronesian period; how is the

\footnotetext{
${ }^{2}$ Based on big event model, it is believed that big events that brought big changes in various fields will become the bases of the initial cultural development period (Simanjuntak and Harry Widianto, 2012). That is the basis of Simanjuntak's division of Austronesia into Prehistoric Austronesia (early 2000 BP), Proto-historic Austronesia (2000 BP - early $4^{\text {th }}-5^{\text {th }}$ centuries AD), and Recent Austronesia (Independence period until now), which was focused on indigenous cultures (Simanjuntak, 2015: 38).
}

dispersal pattern of the menhirs, and who were the bearers of the culture. This study will show the distribution of the menhirs in Lima Puluh Koto area and who were the bearers of this tradition.

The aim of this article is to know the form and dispersal of megalithic culture as well as the Austronesian migration Lima Puluh Koto Area. Furthermore, this research also attempts to reveal the way of life of the bearers of megalithic culture in Lima Puluh Koto Area, which are thought to be the Asutronesian-speaking migrants. The practical benefit of this research is that it can be used as an development plan of the local government as a Cultural Tourism Destination.

\section{METHODS}

Certain methods and techniques
are required in research implementation and analysis/data processing. During observation, data collecting was carried out through bibliographycal study, survey, and excavation. Description writing, measuring, photograph-making, and drawing were also carried out. In description phase these were laboratory and non laboratory analyses, particularly dating analyses. Furthermore, during explanation, data collecting phase there were interpretation based on synthesa on data that have been analyzed in the previous phase. Then they were intergrated with data obtained from historic analogy and ethnographic studies. Therefore this research is qualitative in nature, in which empirical facts from the field were noted and inferenced as preliminary conclusion from observable data. This method is focused on interactive relations 


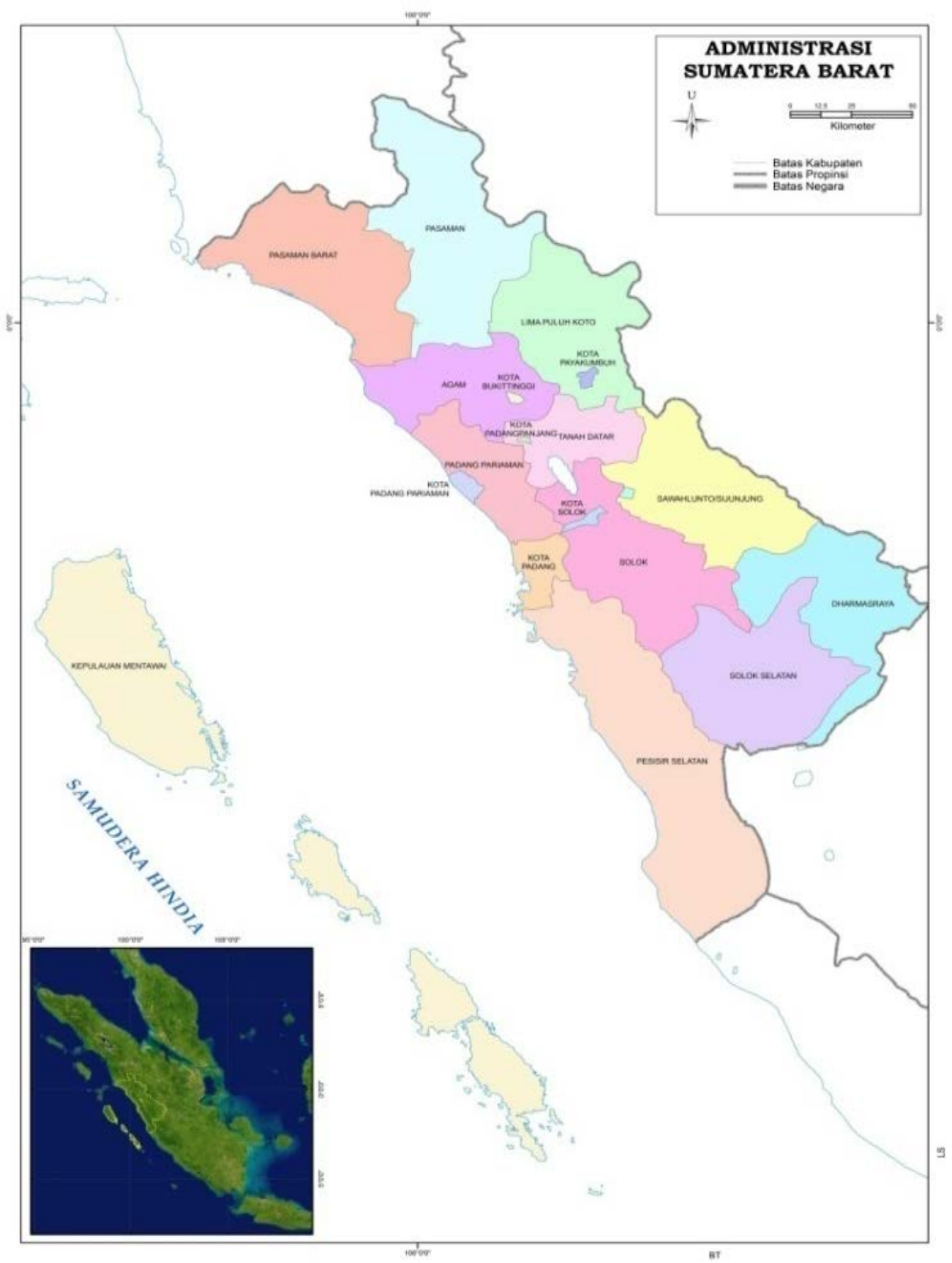

Figure 2. Map of Lima Puluh Koto, West Sumatera, (Source: Report on Field Research, 2009) 


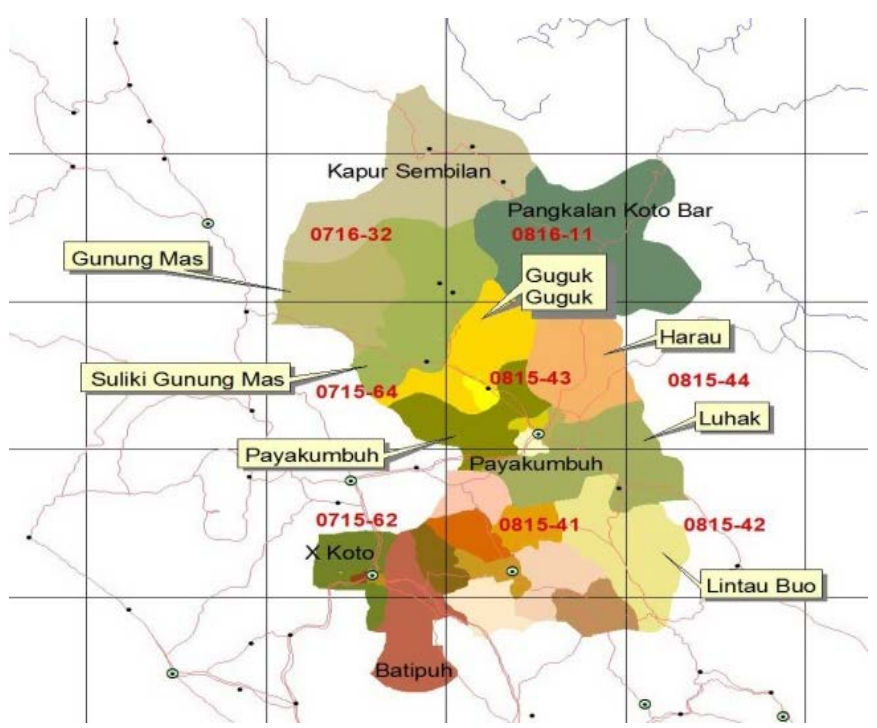

Figure 3. Lima Puluh Koto Regency. Source: Report on Field Research, 2009)

The highest mountain in Lima Puluh Koto is Mount Sago (2261 m). However, the upright menhirs with curvature on the upper parts are not always oriented towards the highest mountain, but towards the nearest mountain or hill. They are distributed in eight out of the thirteen districts in the regency, namely Gunung Omeh, Suliki, Bukit Barisan, Harau, Pangkalan Koto Baru, Akabiliru, and Guguk. Researches reveal that the district with the most Megalithic (menhir) sites is Guguk Regency and Mungka, with 13 sites that contain \pm 131 menhirs, while the site with the most menhirs is Koto Tinggi Mahat in Bukit Barisan District, where \pm 350 menhirs are found. The district of Bukit Barisan has six menhir sites with cluster arrangements. Some clusters have menhirs with linear layout with other menhirs around them; sometimes there are also dolmens or stone mortars and monoliths with one or more pits (pit-marked stones), some of them have decorations at the edges. The total number of menirs is \pm 878 , which may increase with new discoveries when people clean their fields, open new agricultural fields, or dig on their rice fields.

If we pass through the streets of those districts, we can easily find menhirs at junctions, people's front or back yards, schoolyards, in front or back of mosques, at the border of agricultural fields within a village or between villages, in the rice fields, in the forest, as well as at the feet or on the ridge of hills. Some of the menhirs have fallen down, but some are still in upright position. Their sizes varied. The height of big ones are nearly $3 \mathrm{~m}$, while the short ones have a length/height of $50-100 \mathrm{~cm}$. One of the characteristics of Lima puluh Koto menhirs is a type of decoration shaped like vines known as 'keluak paku's. There are also

\footnotetext{
${ }^{4}$ Keluak paku is the tip of (bud) of 'paku' plant (fern) commonly found on mountain orlereng pegunungan dan perbukitan. Lihat: Triwurjani, 2012. "Ragam Hias 'Keluak Paku' pada Menhirmenhir di Kabupaten Lima Puluh Koto, Sumatera Barat. Arkeologi Untuk Publik Jakarta: Ikatan Ahli Arkeologi Indonesia (IAAI), Wedatama Widya Satra, hlm. 808-824.
} 
some that are plain and the upper parts curved and pointed to one side like a sword's handle (Haris Sukendar, 1984). Other decorations include triangles, geometric, weapon, and human parts like arm and finger. The menhirs are placed on plains at the bottom of hills or on hill ridge as seen in photograph 1-8.
The vastbess dispersal the menhirs, which are found at almost every district in Lima Puluh Koto Regency, can be seen in the following table, which is the Table of Megalithic Site Dispersal in Lima Puluh Koto Area, West Sumatera Province.

Table 1. Distribution of Megalithic Sites in Lima Puluh Koto Area. West Sumatera Province (Source: BP3 Batu Sangkar, Laporan Penelitian, 2010; Triwurjani, 2012).

\begin{tabular}{|c|c|c|c|c|c|c|c|c|c|}
\hline \multirow{2}{*}{ No } & \multirow{2}{*}{$\begin{array}{c}\text { District/ } \\
\text { Kanagarian }\end{array}$} & \multirow{2}{*}{$\begin{array}{l}\text { Name of } \\
\text { Site }\end{array}$} & \multirow{2}{*}{$\begin{array}{c}\text { Amoung } \\
\text { of } \\
\text { Objects }\end{array}$} & \multicolumn{3}{|c|}{ Type of Object } & \multicolumn{3}{|c|}{ Coordinate } \\
\hline & & & & $\begin{array}{c}\text { Flat } \\
\text { Stone }\end{array}$ & Menhir & $\begin{array}{c}\text { Pit- } \\
\text { marked } \\
\text { Stone }\end{array}$ & $\begin{array}{l}\text { Stone } \\
\text { Mortar }\end{array}$ & $\begin{array}{c}\text { Eastern } \\
\text { Hemisphere }\end{array}$ & $\begin{array}{l}\text { Southern } \\
\text { Latitude }\end{array}$ \\
\hline \multicolumn{10}{|c|}{ 1. Gunung Omeh District } \\
\hline 1 & Koto Tinggi & $\begin{array}{l}\text { Batu } \\
\text { Talempong }\end{array}$ & 47 & - & 47 & - & - & $100^{\circ} 23^{\prime} 30^{\prime \prime}$ & $0^{0} 4^{\prime} 75^{\prime \prime}$ \\
\hline 2 & Koto Tinggi & Koto Tinggi & 24 & - & 24 & - & - & $100^{0} 21^{\prime} 28.4 "$ & $0^{0} 3^{\prime} 3.1^{\prime \prime}$ \\
\hline 3 & $\begin{array}{l}\text { Pandam } \\
\text { Gadang }\end{array}$ & Bukit Apar & 81 & - & 81 & - & - & $100^{\circ} 25^{\prime} 56^{\prime \prime}$ & $0^{0} 05^{\prime} 45^{\prime \prime}$ \\
\hline \multicolumn{10}{|c|}{ 2. Suliki District } \\
\hline 4 & Anding & Anding I & 17 & . & 17 & - & - & $100^{\circ} 30^{\prime} 29^{\prime \prime}$ & $0^{0} 5^{\prime} 12^{\prime}$. \\
\hline 5 & Anding & Anding II & 15 & - & 15 & - & - & $100^{\circ} 30^{\prime} 37^{\prime \prime}$ & $0^{0} 5^{\prime} 11^{\prime \prime}$ \\
\hline 6 & Suliki & Limbanang I & 16 & - & 16 & - & - & $100^{\circ} 30^{\prime} 11^{\prime \prime}$ & $0^{0}$ 6’ 19” \\
\hline 7 & Suliki & $\begin{array}{l}\text { Limbanang } \\
\text { II }\end{array}$ & 8 & - & 8 & - & - & $100^{\circ} 30^{\prime} 16^{\prime \prime}$ & $0^{0}$ 6’20”' \\
\hline \multicolumn{10}{|c|}{ 3. Bukit Barisan District } \\
\hline 8 & Mahat & Koto Tinggi & 350 & - & 350 & - & - & $100^{\circ} 29^{\prime} 41^{\prime \prime}$ & $0^{0} 01^{\prime} 40^{\prime \prime}$ \\
\hline 9 & Mahat & Ronah & 15 & - & 15 & - & - & $100^{\circ} 30^{\prime} 13^{\prime \prime}$ & $0^{0} 01^{\prime} 36^{\prime \prime}$. \\
\hline 10 & $\begin{array}{l}\text { Padang } \\
\text { Ilalang }\end{array}$ & $\begin{array}{l}\text { Padang } \\
\text { Ilalang }\end{array}$ & 29 & - & 29 & - & - & $100^{\circ} 30^{\prime} 22^{\prime \prime}$ & $0^{0} 01^{\prime} 56^{\prime \prime}$ \\
\hline 11 & Mahat & $\begin{array}{l}\text { Sopan } \\
\text { Tanah }\end{array}$ & 13 & - & 13 & - & - & $100^{\circ} 30^{\prime} 45^{\prime \prime}$ & $0^{0} 01^{\prime} 51^{\prime \prime}$ \\
\hline 12 & Mahat & $\begin{array}{l}\text { Koto } \\
\text { Gadang }\end{array}$ & 30 & - & 30 & - & - & $100^{\circ} 30^{\prime} 34^{\prime \prime}$ & $0^{0} 00^{\prime} 58^{\prime \prime}$, \\
\hline 13 & Mahat & Domo & 31 & & 31 & - & - & $100^{\circ} 30^{\prime} 23^{\prime \prime}$ & $0^{0} 01 ’ 49^{\prime \prime}$ \\
\hline \multicolumn{10}{|c|}{ 4. K Harau District } \\
\hline 14 & $\begin{array}{l}\text { Labua } \\
\text { Batingko }\end{array}$ & $\begin{array}{l}\text { Lubuk } \\
\text { Batingkok }\end{array}$ & 3 & 1 & 1 & - & 1 & $100^{\circ} 37^{\prime} 19^{\prime \prime}$ & $0^{0} 10^{\prime} 07^{\prime \prime}$ \\
\hline 15 & Gurun & Gurun I & 8 & - & 3 & - & 5 & $100^{\circ} 37^{\prime} 30^{\prime \prime}$ & $0^{0} 09^{\prime} 38^{\prime \prime}$. \\
\hline 16 & Gurun & Gurun II & 5 & - & 5 & - & - & $100^{\circ} 37^{\prime} 34^{\prime \prime}$ & $0^{0} 09^{\prime} 26^{\prime \prime}$ \\
\hline 17 & Gurun & Gurun III & 9 & - & 9 & - & - & $100^{\circ} 37^{\prime} 38^{\prime \prime}$ & 0099'16” \\
\hline 18 & Taram & $\begin{array}{l}\text { Gua Taram } \\
\text { I }\end{array}$ & 1 & - & - & 1 & - & $100^{\circ} 41^{\prime} 02 "$ & $0^{0} 12^{\prime} 59^{\prime \prime}$ \\
\hline 19 & Andaleh & $\begin{array}{l}\text { Gua Taram } \\
\text { II }\end{array}$ & 2 & - & - & 2 & - & $100^{\circ} 41^{\prime} 46^{\prime \prime}$ & $0^{0} 13^{\prime} 29 ”$ \\
\hline
\end{tabular}




\begin{tabular}{|c|c|c|c|c|c|c|c|c|c|}
\hline \multicolumn{10}{|c|}{ 5. Pangkalan Koto Baru District } \\
\hline 20 & $\begin{array}{l}\text { Pangkalan } \\
\text { Koto }\end{array}$ & $\begin{array}{l}\text { Pangkalan } \\
\text { Koto Baru }\end{array}$ & 13 & - & 13 & - & - & $100^{\circ} 43^{\prime} 20^{\prime \prime}$ & $0^{0} 05^{\prime} 16^{\prime \prime}$ \\
\hline \multicolumn{10}{|c|}{ 6. Akabiliru District } \\
\hline 21 & Pauh & $\begin{array}{l}\text { Pauh } \\
\text { Sangik }\end{array}$ & 16 & - & 16 & - & - & $100^{\circ} 28^{\prime} 43^{\prime \prime}$ & $0^{0} 09^{\prime} 44^{\prime \prime}$ \\
\hline 22 & Pauh & Batu Bajari & 9 & 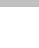 & 9 & 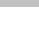 & 4 & $100^{\circ} 29^{\prime} 01$ & $0^{0} 09^{\prime} 57^{\prime \prime}$ \\
\hline 23 & Suri Laweh & $\begin{array}{l}\text { Batu } \\
\text { Giriang }\end{array}$ & 2 & - & 2 & - & - & $100^{\circ} 32^{\prime} 15^{\prime \prime}$ & $0^{0} 12^{\prime} 49^{\prime \prime}$ \\
\hline \multicolumn{10}{|c|}{ 7. Guguk District } \\
\hline 24 & Kuranji & Kuranji & 1 & - & 1 & - & - & $100^{\circ} 33^{\prime} 55^{\prime \prime}$ & $0^{0} 09^{\prime} 59 ”$ \\
\hline 25 & Caniago & Balubus & 15 & - & 15 & - & - & $100^{\circ} 33^{\prime} 32 "$ & $0^{0} 10^{\prime} 55^{\prime \prime}$ \\
\hline 26 & $\begin{array}{l}\text { Sungai } \\
\text { Taram }\end{array}$ & Subarang & 1 & - & 1 & - & - & $100^{\circ} 33^{\prime} 24^{\prime \prime}$ & $0^{\circ} 10^{\prime} 57^{\prime \prime}$ \\
\hline 27 & $\begin{array}{l}\text { Sungai } \\
\text { Talang }\end{array}$ & $\begin{array}{l}\text { Sungai } \\
\text { Talang I }\end{array}$ & 6 & - & 6 & - & 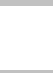 & $100^{\circ} 31^{\prime} 15^{\prime \prime}$ & $0^{\circ} 06^{\prime} 07^{\prime \prime}$ \\
\hline 28 & $\begin{array}{l}\text { Sungai } \\
\text { Talang }\end{array}$ & $\begin{array}{l}\text { Sungai } \\
\text { Talang II }\end{array}$ & 30 & - & 30 & - & - & $100^{\circ} 32^{\prime} 13^{\prime \prime}$ & $0^{0} 09^{\prime} 50 "$ \\
\hline 29 & $\begin{array}{l}\text { Sungai } \\
\text { Talang }\end{array}$ & Tanah Sirah & 6 & - & 6 & - & - & $100^{\circ} 32^{\prime} 18^{\prime \prime}$ & $0^{\circ} 10^{\prime} 07 "$ \\
\hline 30 & Kubang & Kubang & 5 & - & 5 & - & - & $100^{\circ} 29^{\prime} 45^{\prime \prime}$ & $0^{\circ} 08^{\prime} 39^{\prime \prime}$ \\
\hline 31 & Tujuh Koto & $\begin{array}{l}\text { Balai } \\
\text { Mansiro }\end{array}$ & 4 & - & 4 & - & - & $100^{\circ} 32^{\prime} 21 "$ & $0^{0} 07^{\prime} 50^{\prime \prime}$ \\
\hline 32 & $\begin{array}{l}\text { Guguk } \\
\text { Nunang }\end{array}$ & $\begin{array}{l}\text { Guguk } \\
\text { Nunang }\end{array}$ & 22 & - & 22 & - & - & $100^{\circ} 33^{\prime} 33^{\prime \prime}$ & $0^{0} 10^{\prime} 30^{\prime \prime}$ \\
\hline 33 & Guguk & Sati & 10 & - & 8 & - & 2 & $100^{0} 33^{\prime} 16,7^{\prime \prime}$ & $0^{0} 10^{\prime} 31,6 "$ \\
\hline 34 & Guguk & Guguk & 8 & - & 8 & - & - & $100^{\circ} 33^{\prime} 43,7^{\prime \prime}$ & 0 08'52,2" \\
\hline 35 & $\begin{array}{l}\text { Ampang } \\
\text { Gadang }\end{array}$ & $\begin{array}{l}\text { Ampang } \\
\text { Gadang }\end{array}$ & 8 & - & 8 & - & - & $100^{\circ} 29^{\prime} 19^{\prime \prime}$ & $0^{\circ} 00^{\prime} 35^{\prime \prime}$ \\
\hline 36 & Koto Kaciak & Koto Kaciak & 7 & - & 7 & - & - & $100^{\circ} 31^{\prime} 16^{\prime \prime}$ & $0^{\circ} 06^{\prime} 07^{\prime \prime}$ \\
\hline \multicolumn{10}{|c|}{ 8. Mungka District } \\
\hline 37 & $\begin{array}{l}\text { Padang } \\
\text { Jopang }\end{array}$ & $\begin{array}{l}\text { Padang } \\
\text { Jopang }\end{array}$ & & & & & - & $100^{\circ} 33^{\prime} 03^{\prime \prime}$ & $0^{\circ} 06^{\prime} 40^{\prime \prime}$ \\
\hline & $\begin{array}{c}24 \\
\text { Kanagarian }\end{array}$ & 37 Situs & 878 & 1 & 862 & 3 & 12 & & \\
\hline
\end{tabular}

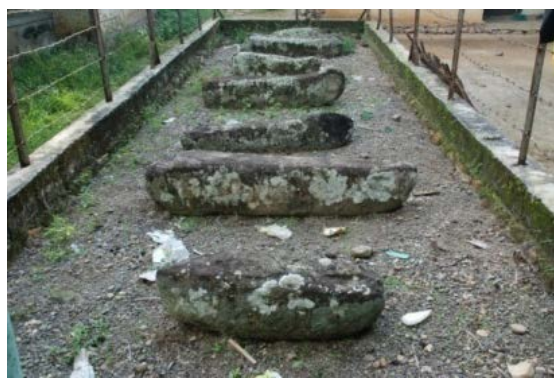

Figure 4. Fallen down straight-shaped menhirs from Sei Talang I Site (Doc. the Author)

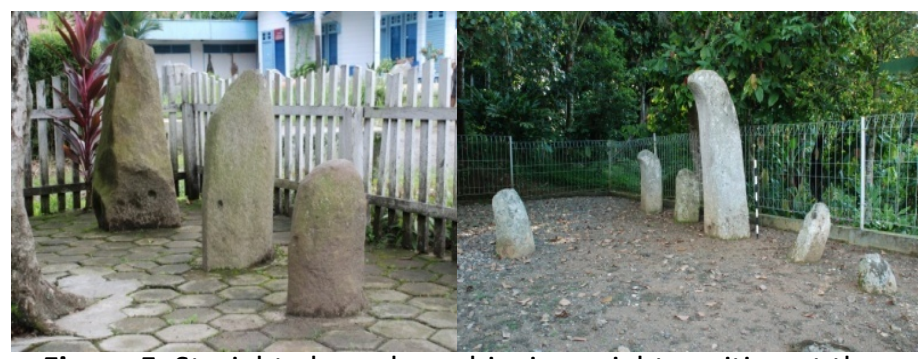

Figure 5. Straight-shaped menhirs in upright position at the site of Ampang Gadang (left) and a type of menhirs with curved top that inclined to certain direction, found at. Tanah Sirah. Site (right). (Doc.the Author) 


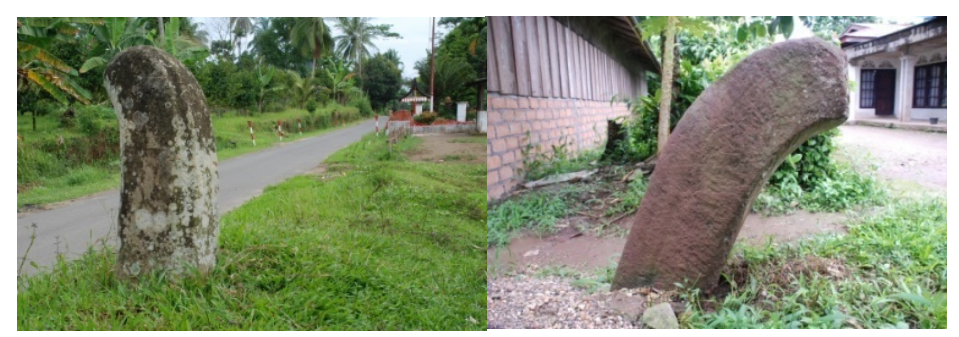

Figure 6. Menhirs along village roads which shapes are curving like sword's handles at Guguk Site (Doc. the Author)

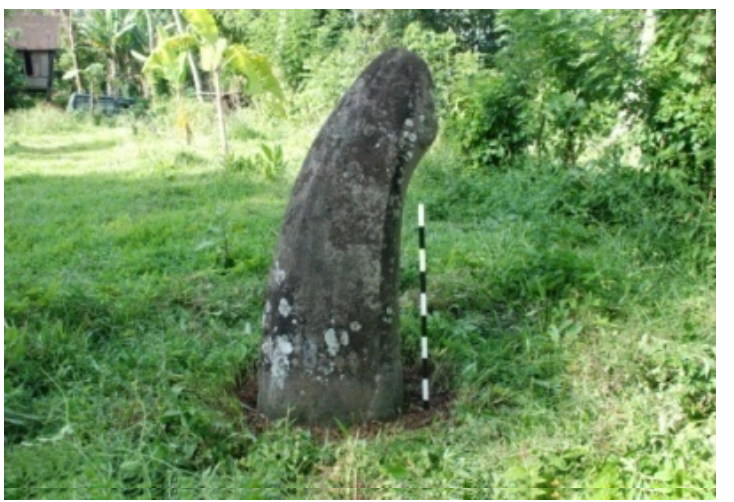

Figure 7. Menhirs that shaped like sword's handles (curving) in a field within the site of Subarang (Doc. the Author)

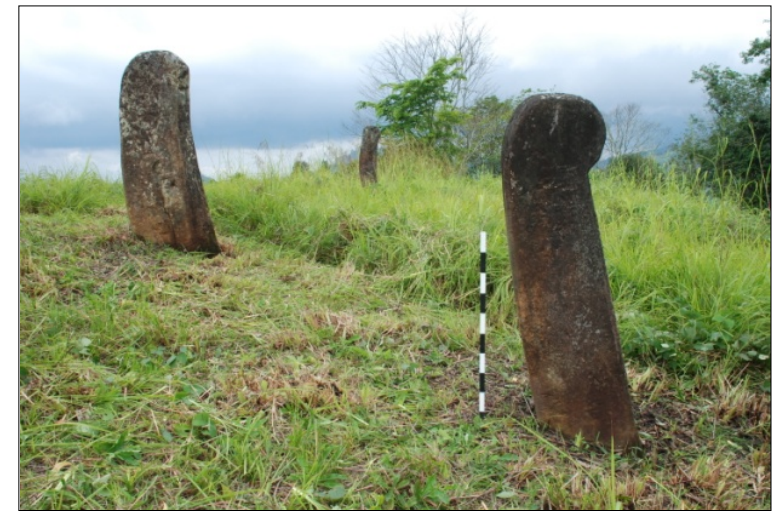

Figure 8. Upright menhir on a Hilltop at Bukit Apar Site. The top parts are shaped like sword's handles (Doc. the Author)

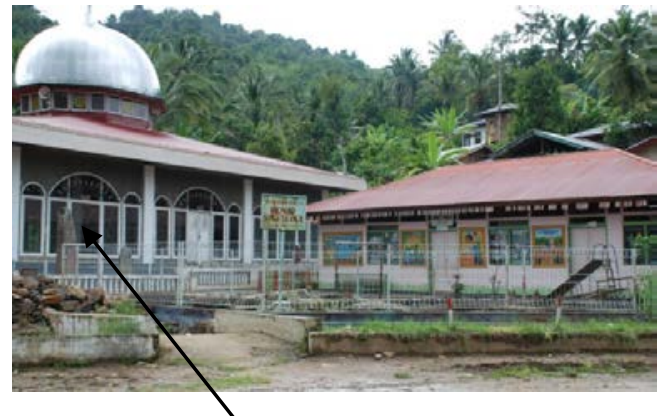

Figure 10. Menhir at the Courtyard of a Mosque, Sei Talang Site II. (Doc.the Author)

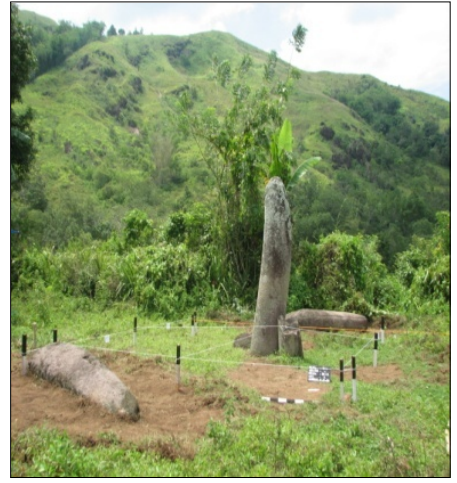

Figure 9. Upright menhirs on the foot of a hill at Sati Site, which top parts are inclined to a certain direction (Doc.the Author)

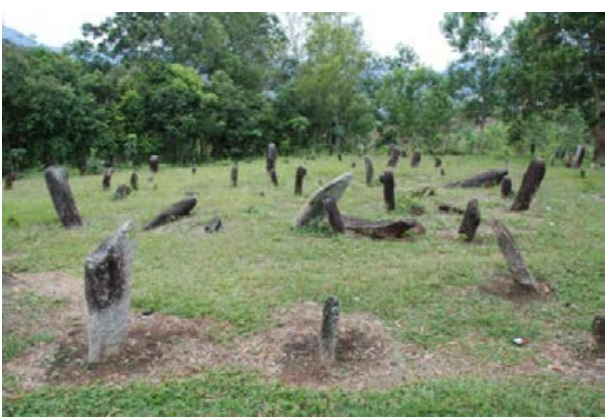

Figure 11. A complex of straight- and curving-shaped menhirs at the edge of a forest at Bawah Parit Site (Doc.the Author) 


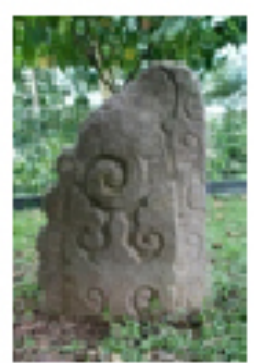

Tendrils, elubus

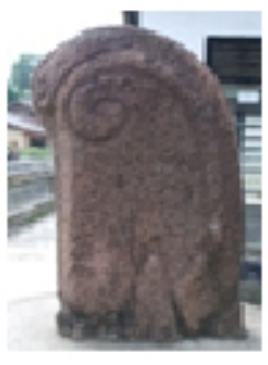

Tendrils, Lubuk Batingkok

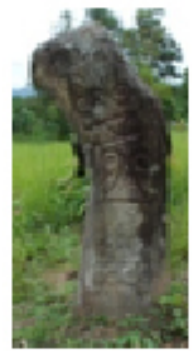

Incised, Koto Tingg

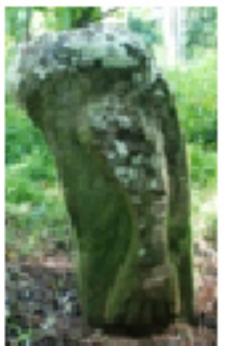

Hand, Bajari, left side

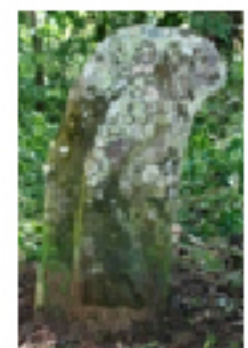

Hand, Bajari right side

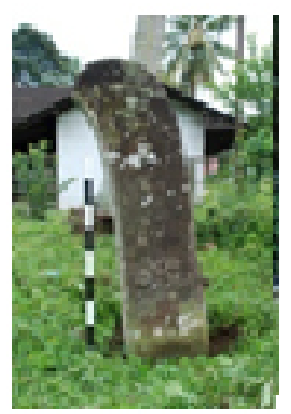

Sword's handle Ampang Gadang

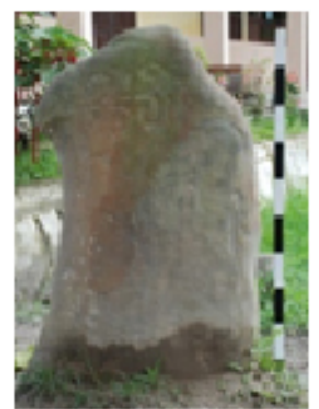

Tendrils: Sopan Tanah

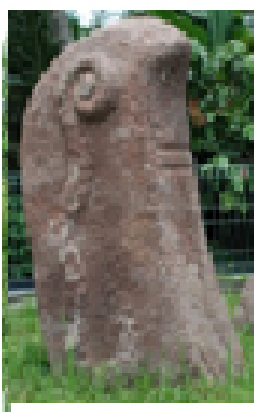

Keluak paku/fern, Belubus

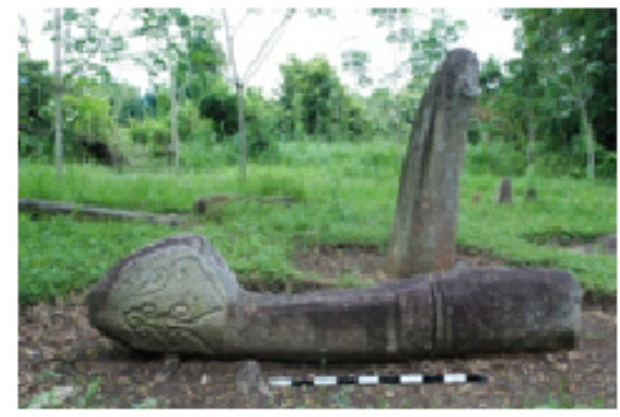

Keluak paku/fern, Situs Koto Gadang

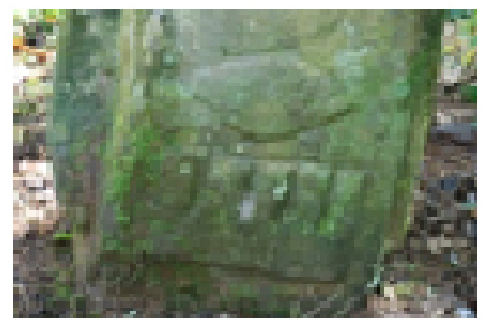

Detail motif hias, Bajari

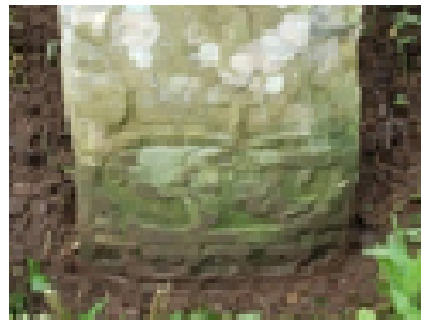

Motif hias, Menhir Ampang Gadang

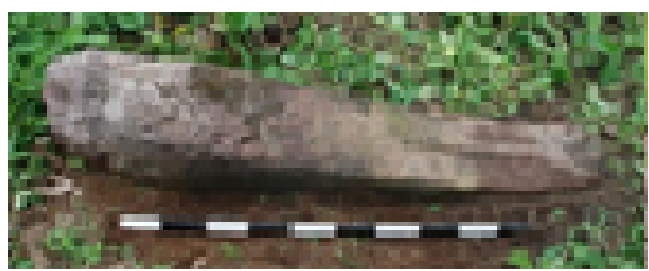

Keluak paku/fern', Batu Giring

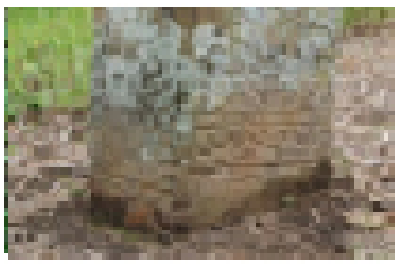

Tendrils: Koto Tinggi

Figure 12. Ornament Motifs of Menhir Lima Puluh Kuto. (Doc. Author) 
The layout of the menhirs, although some are single and the others are in groups, can be categorized into big groups within the area. Each group consists of one
Anding 2, Koto Kaciak, Limbanang, Baruah, Ampang Gadang, Simpang Masiro, and Padang Jopang. Group IV is a valley with secondary forest and consists of the sites of Taratak

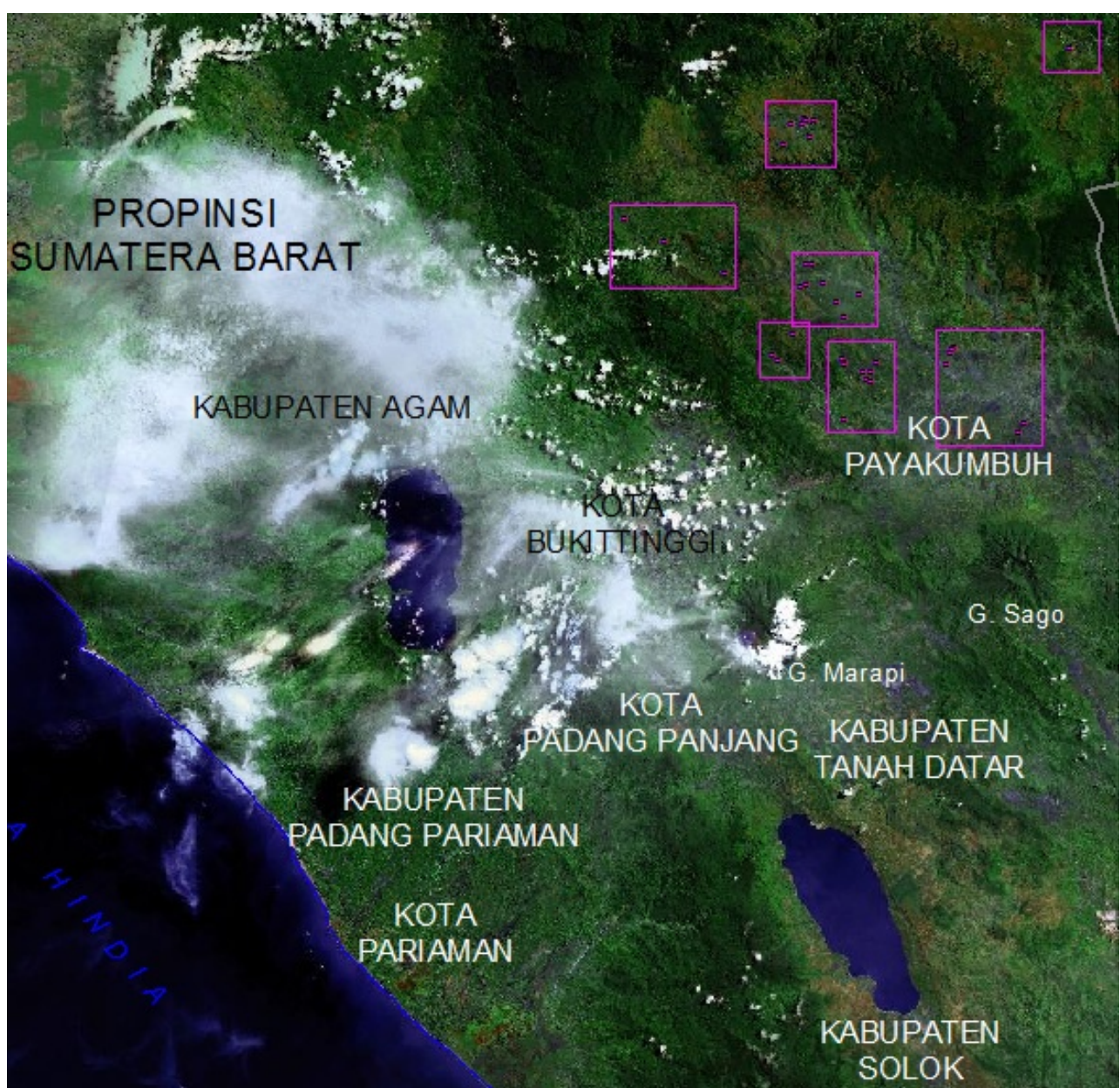

Figure 13. Groups of menhirs in Lima Puluh Koto area, Based on the Physical character of the area and similarity of raw material.

or several sites. There are seven groups based on similarities of physical morphology, type of rock, and location. Group $\mathrm{I}$ is a hilly highland and consists of Gunung Omeh, Batu Talempong, and Bukit Apar. Group II has valley morphology consists of the site of Koto Tinggi, Padang Ilalang, Sopan Tanah, Domo, Koto Gadang, Ronah, and Ampang Gadang Sungai. Group III has lowland morphology and consists of the sites of situs Anding1,
Kubang, Pauh Sangik, and Bajari. Group $V$ is a valley at the foot of hills and consists of the sites of Talang 1 , Talang 2, Sati, Subarang, Kuranji, Guguk Nunang, and Belubus. Group $\mathrm{VI}$ is a valley morphology consists of Gurun 1, Gurun 2, Gurun 3, Lubuk Batingkok, Taram, and Andaleh. Group VII is at the foot of a hill is located farthest to the northeast consists of one site namely Pangkalan Koto Baru. 


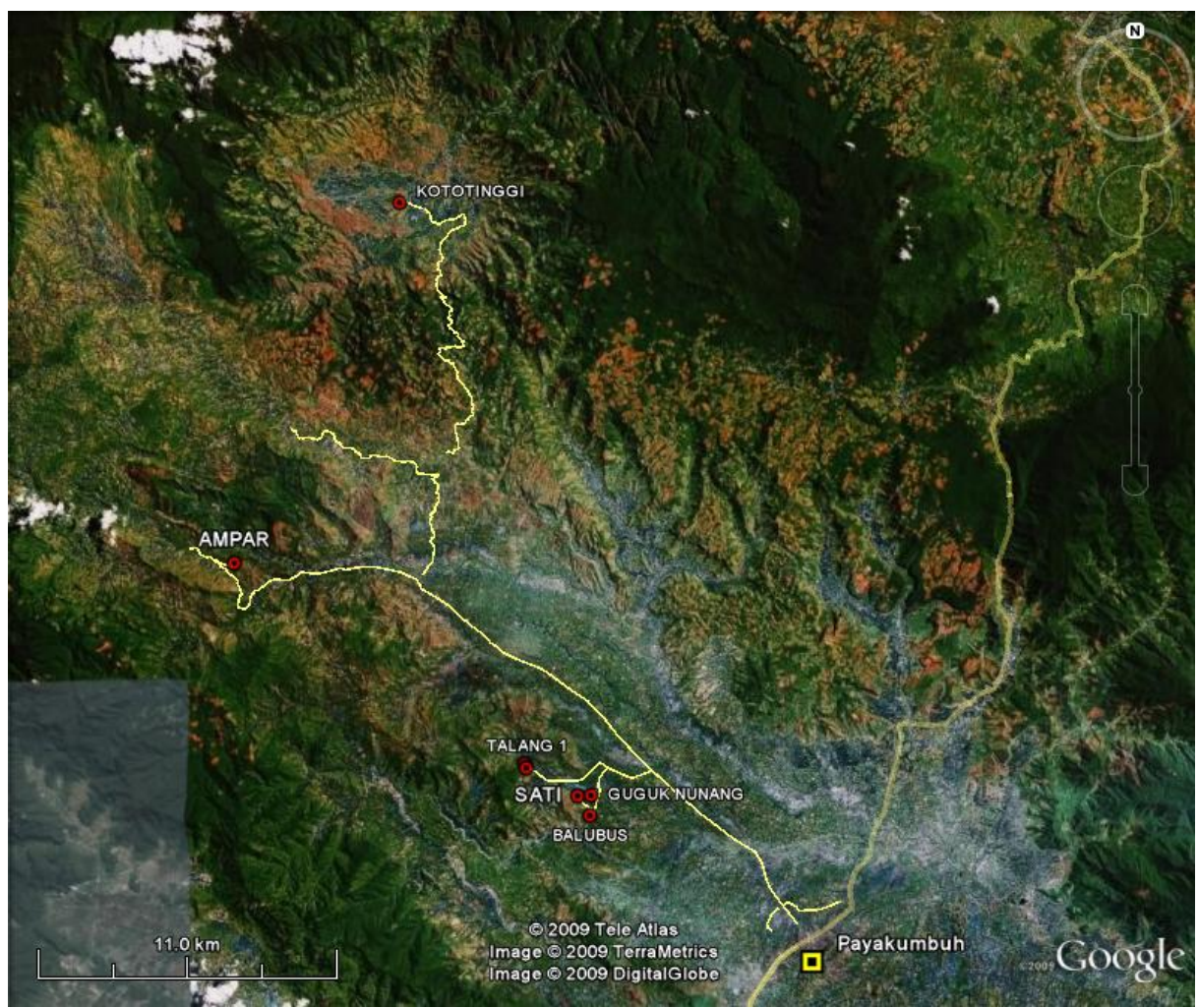

Figure 14. The Road Network Connecting Menhirs, which disperse in Lima Puluh Koto Area

The highest group of menhirs, which is located on top of the ridge of a hill, is Group I, while the farthest is Group VII, Pangkalankoto Baru. The other groups are located on valleys. In order to know the functions of menhirs at every site, as well as the characteristic of each menhir site, excavations were carried out randomly at a site on highland area and on a valley, which are Sati and Bukit Apar. Both sites have different distribution characteristics, one clustered together (Sati) and the other dispersed (Bukit Apar).

Based on their shapes, functions, and locations, in general the menhirs of Lima Puluh Koto are straight with the top or the upper one third parts curved and inclined to certain direction (chtonis). However, there is also an upright stone menhir with a wide body. A slim-shaped menhir is usually $2-2.5 \mathrm{~m}$ high with a tapered end. The functions of menhirs are varied according to the observations on the distributions and positions of menhirs in certain locations. One function is as a tombstone for one particular group of menhirs and it has context with other findings. Another function of menhirs is as a village boundary monument, and even as an area marker monument. There are still a lot of discussions about the specific functions of menhirs at each site depending on the context of the surrounding of the findings. However, only general functions that can be put forward in this discussion.

\section{THE SITE OF SATI}

Sati is a megalithic site on the feet of hills of Guguk Village, Guguk District, Lima Puluh Koto Regency. Austronomically this site is located in between $100^{\circ} 33^{\prime} 16,7^{\prime \prime} \quad$ Eastern 
Hemisphere and $0^{\circ} 10^{\prime} 31,6^{\prime \prime}$ Southern Latitude. Standing and lay down down menhirs, pit-marked stones, and stone troughs located this site. A number of menhirs are clustered at the feet of Batu Perisai (Perisai Hill), which stands $\pm 800 \mathrm{~m}$ above the sea level, in northwest direction, is Merapi mount $( \pm 2891 \mathrm{~m}$ high) that is the highest mountain in
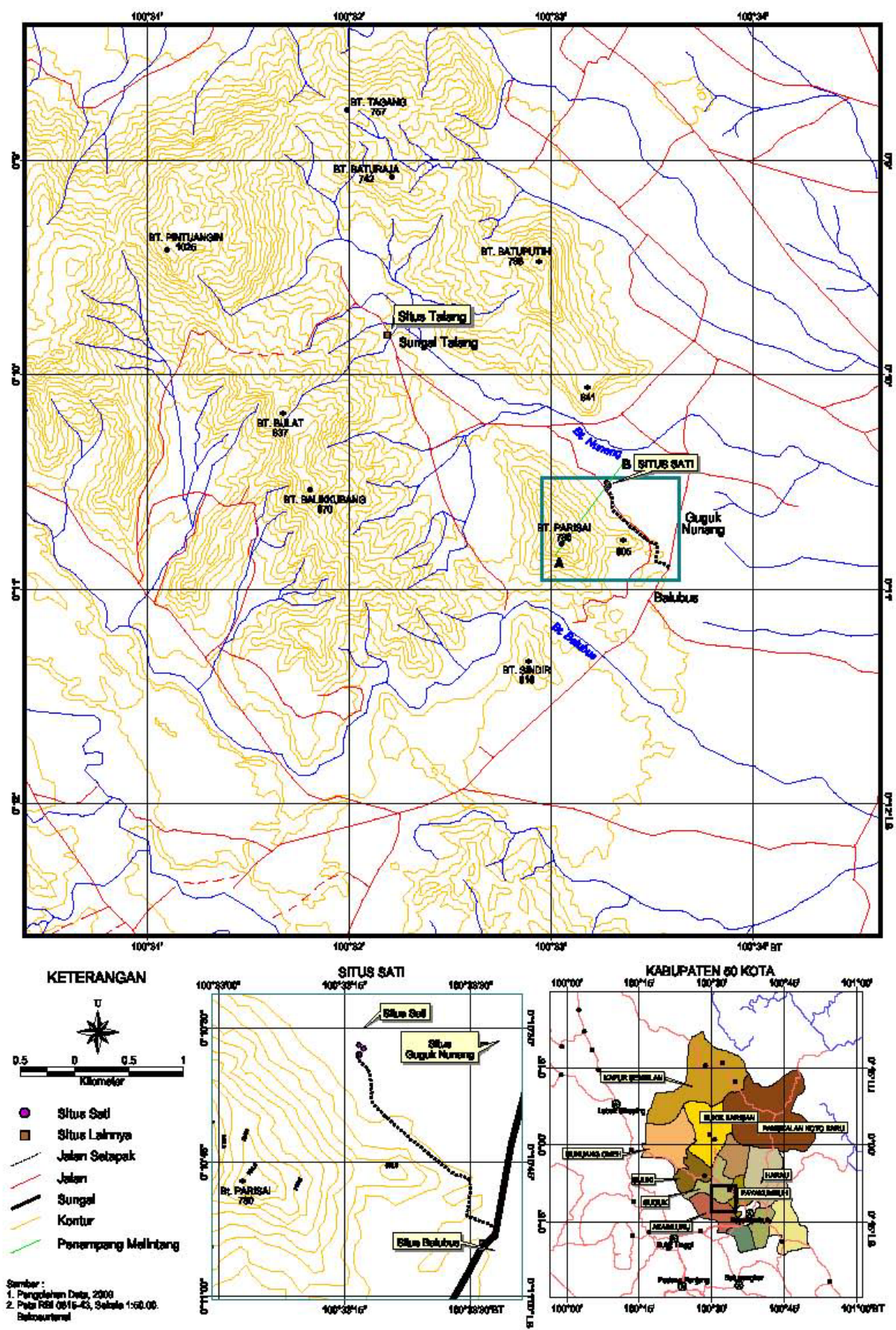

Figure 15. Sati Site Location, Lima Puluh Koto Region, Source: Research Report, 2009, Triwurjani, et. al, 2012:13) 
West Sumatera. Besides Mount Merapi, to the southesat Perisai Hill is Mount Sago, which is $\pm 1863 \mathrm{~m}$ high. In other words Perisai Hill is surrounded by mountains and hills. It is to its east that there are standing menhirs amongst the lay down ones.
Mount Merapi. There were also menhirs decorated vine/scroll shape or "keluak paku" (fern).

Two excavation pits were openend, namely U1T1 and U2T2, to investigate the function and role of menhirs found there. The results are
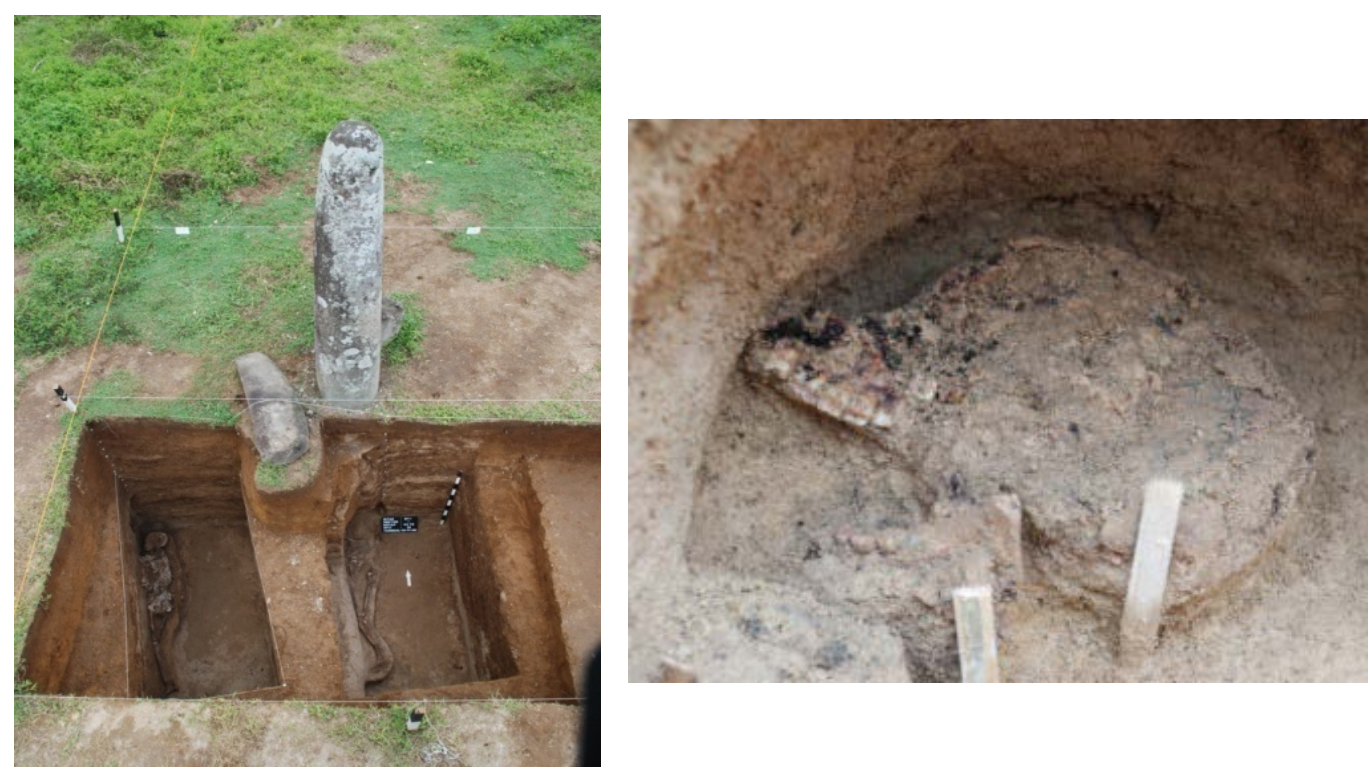

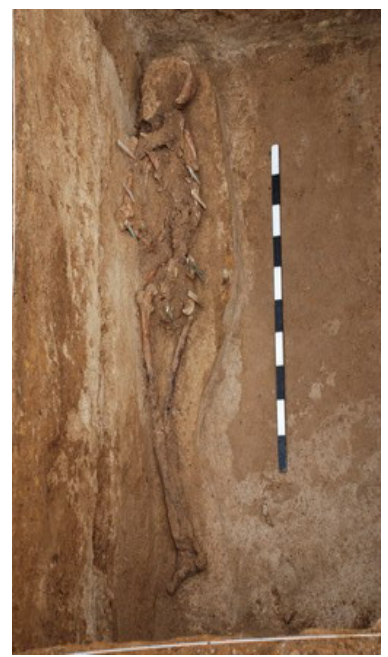

Skeleton1

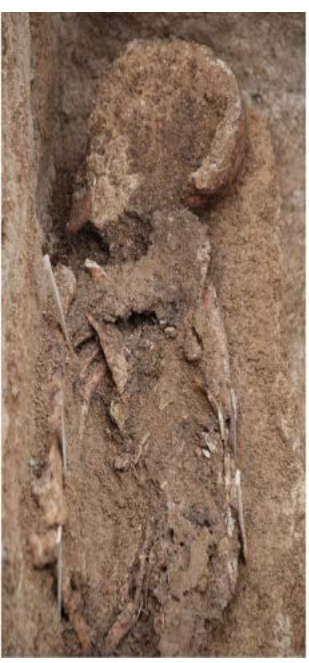

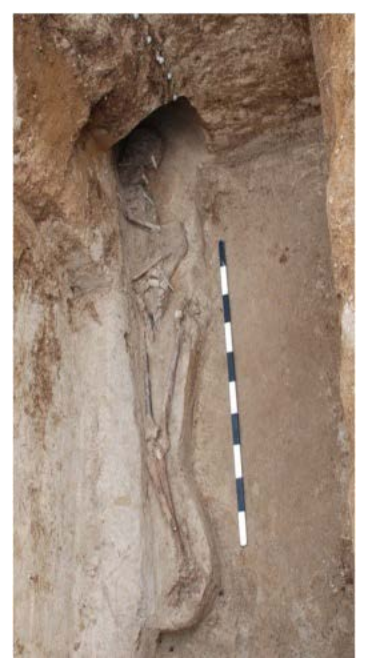

Skeleton2

Figure 16. Excavation of Sati Site, Guguk District, Lima Puluh Koto Regency.

(Doc. The Author.)

The top parts were shaped in curving forms and look as if they face certain direction (chtonic): to the west facing Perisai Hill or facing the discovery of human pottery fragments and 19 th- 20 th century $A D$ porcelains are still found. Skeleton 1 (R1) is found in U1T1 pit. 


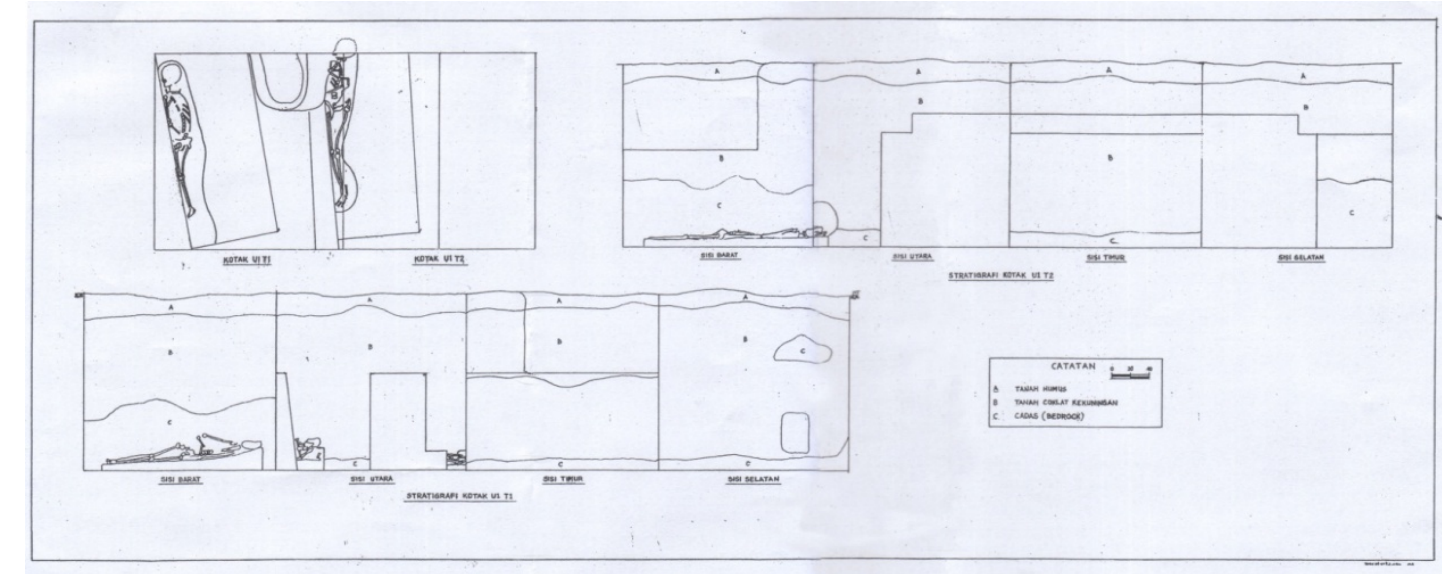

Figure 17. Stratigraphy of Sati site, Guguk District, Lima Puluh Koto Regency. Source: Research Report, 2009, Triwurjani, et. al, 2012:13)

R1 was found at the depth of \pm 180 $\mathrm{cm}$ in sideways position, attached to feature wall with its head in northwest and its feet in southeast is seen on it. Its jaws are closed with intact teeth.

$\mathrm{R} 2$ is found from head to feet in extended position, with its head in
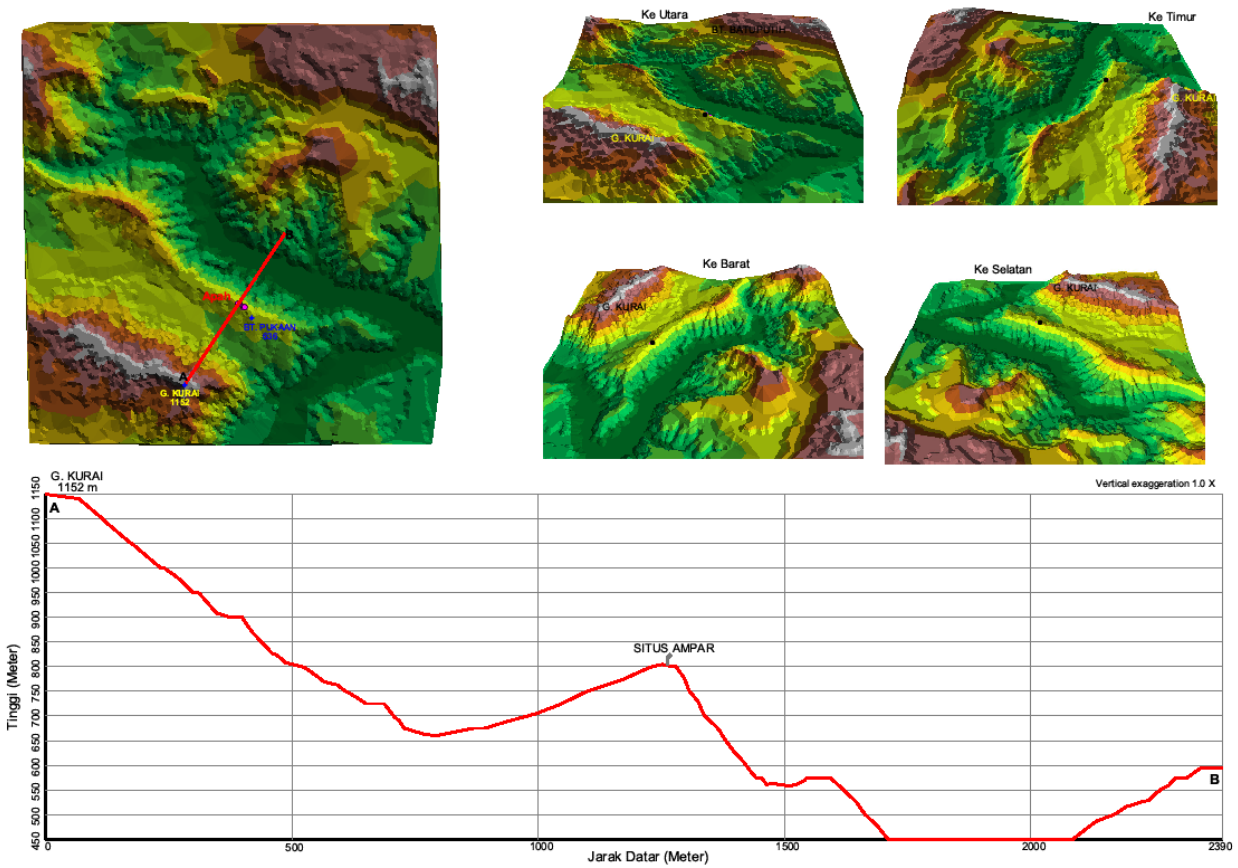

Figure 18. Section of Batu Putih Hill, Bukit Apar Hill, and Mount kurai, Source: Source: Research Report, 2010, Triwurjani, et. al, 2012:13)

directions. Its head to feet are observable, with very fragile and almost broken chest; a folded hand northweat and feet in southeast directions. Its face is oriented towards the southwest, and its chest 
to upper femure are broken. its jaws are opened with protruded shovelshaped teeth. No funeral gift like pottery fragment or stone or metal tool with both skeletons.

\section{THE SITE OF BUKIT APAR}

Bukit Apar Site is located at Pandam Gadang village, Gunung Omeh District Lima Puluh Koto Regency. This site is located in between $100^{\circ} 25^{\prime} 56^{\prime \prime}$ Eastern Hemisphere and $0^{\circ} 05^{\prime} 45^{\prime \prime}$ Southern Latitude. Bukit Apar is also called Bukit Ampar or and to its south is Mount Kurai \pm $1152 \mathrm{~m}$ above sea level. If we draw a straight line from north to south, Batu Putih, Batu Apar Hill, and Mount Kurai are located on one line.

It is quite difficult to reach this site, as we have to climb quite high and vast hill, which cannot be passed by motor bike or car. Menhir in rows both upright and fallen-down position can be found in this site. These menhirs are bigger and taller than those at other sites. The height of the menhirs are up to $200 \mathrm{~cm}$ with a thickness of $\pm 1,5 \mathrm{~cm}$ decor. The

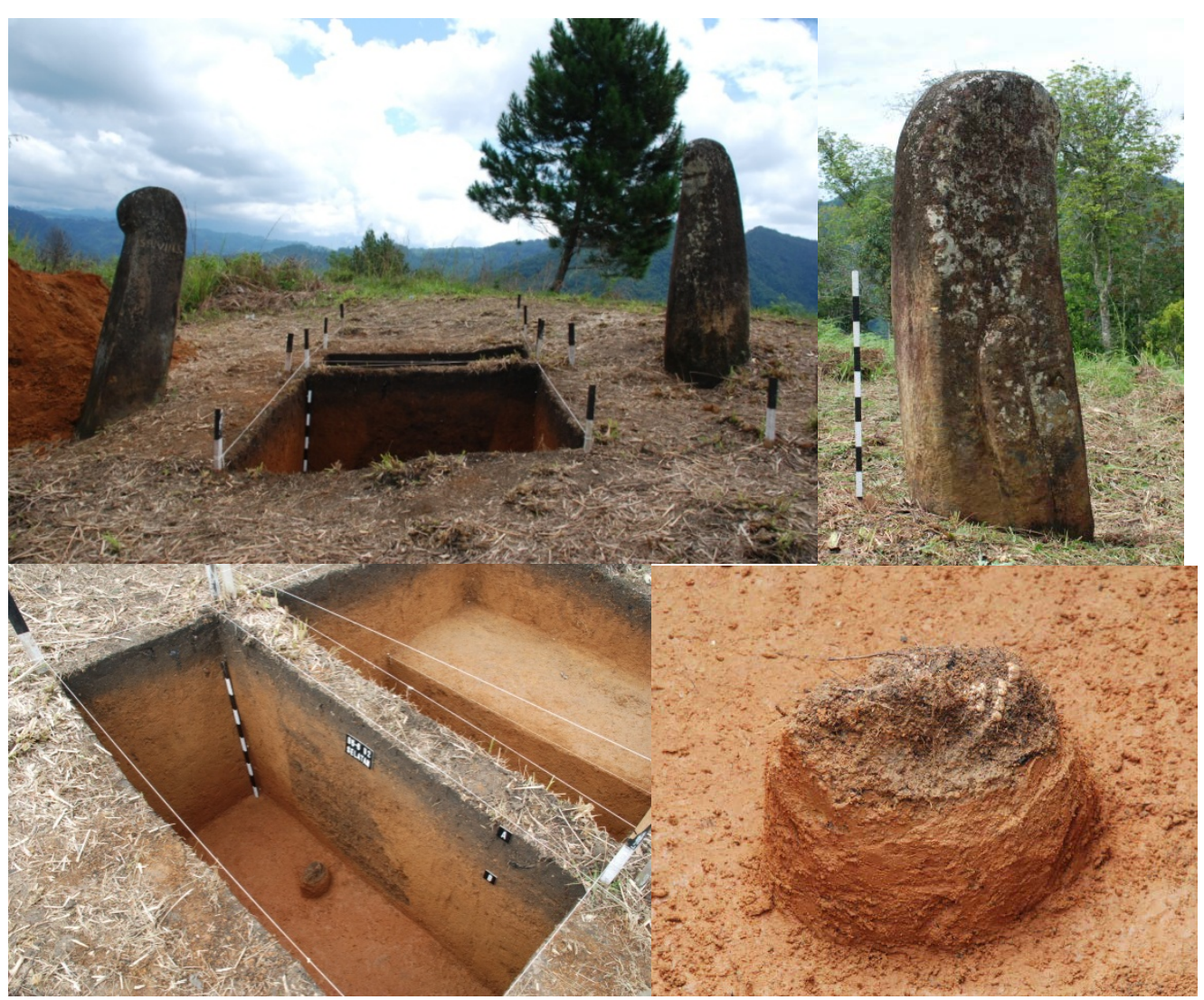

Figure 19. Excavation of Bukit Apar Site, Lima Puluh Koto Area, Source: Research Report, 2010, Triwurjani, et.al, 2012: 21)

Bukit Apah by local people. For practical reason, in this article we use the Bukit Apar. It is a highland site on the ridge of Pukaan Hill at an elevation of $\pm 636 \mathrm{~m}$ above sea level. To its north is Batu Putih Hill biggest one is on top of the Pukaan Hill, and its body is decorated with sword holder (weapon) motif. Other decoration is vine/scrolls. The rest of the menhirs are undecorated. There are two excavation pits were opened 
to the depth of $\pm 1,60 \mathrm{~m}$. Only a group of small sized, blackish teeth in fragile condition are found, and no human skeleton are found in both excavation pits.

Data from excavation show menhir sites on highland areas were not used as primary burial but worship area, while the ones on lower areas were used as primary burial place with no burial container. The menhirs serve as burial markers (tombstones). All the menhirs show that the one buried there was considered as an ancestor figure of respected leader. Among the megalithic communities there was a term 'primus interpares', which is a chosen leader who is the greatest among the other leaders.

\section{DATING}

The excavations yielded two human skeletons at Sati Site, while at Bukit Apar Site only fragment of a fragile jaw was found mixed with soil under a menhir. Skeleton 1 was found in sideway position with northwest - southeast orientation at the depth of $1.8 \mathrm{~m}$ below the surface at Sati Site. The bones are fragile and part of torso is shattered; only the head and lower limbs/feet remain. No burial gift is found. Its jaws are also fragile, with small and level teeth. The second skeleton was found at the depth of $1.6 \mathrm{~m}$ with shattered torso and the skull was under a menhir $( \pm 40 \mathrm{~cm}$ from the base of menhir) and is located outside the excavation box. The femur and tibia, and the sole of the feet seem to be in good condition. Those skeletons show archaic characteristics: protruded foreheads, flat occipital, protruded maxilla and teeth, shovel-shaped incisors, and brachycephallic (wide and short skull shape), which are all the characteristics of Mongolid race (Soejono, 1984; Harry Widianto's explanation as an expert in palaeontology and source, 2009).

Results of Radiocarbon (C14) dating on a rib bone show that Skeleton-1 has a chronology of $4^{\text {th }}-$ $5^{\text {th }}$ centuries CE $(1.370 \pm 170 \mathrm{BP})$ while Skeleton-2 has a chronology of $1^{\text {st }}-4^{\text {th }}$ centuries CE $(1.730 \pm 140$ $\mathrm{BP})$; there is a difference of \pm 350 years.

A number of dating analyses were also carried out by Yacob (1992:156) using samples of some human bones from Bawah Parit Site in Koto Tinggi District, at Megalithic area in Lima Puluh Koto, among others by Teuku Yacob (1992: 156), who stated that the people who lived there 2000 - 3000 years ago were Australomelanesids. The dates of Bawah Parit Site are $3500 \pm 100 \mathrm{BP}$; $3000 \pm 1500 \mathrm{BP} ; 2070 \pm 2130 \mathrm{BP}$ (Fadhila A. A, 1977). The date of Guguk Nunang Site, using charcoal as its sample, is $980 \pm 120 \mathrm{BP}$ (Vita, 2005). The existence of the Austromelanesids indicates that prior the arrival of the migrants the area had been inhabited by another group. They were, then, lived harmoniously with the Mongoloid migrants.

This information shows that the human buried under the menhir at Sati is a Mongolid, while modern human of later period. Furthermore, there is a 200 - 350 year gap between them. If menhirs were used as grave markers in early century, this tradition still continue during later period as seen by the use of menhirs as tombstones. Thus some menhirs remain as sacred objects for centuries, while the others found at other locations might be used as milestones that mark the borders of villages. 
The above assumption has yet to be proven because both individual menhirs and those that were placed in pairs might function as grave markers or tombstones. Results of the excavation on the hill ridge at Bukit Apar Site, Gunung Omeh District also show burial activities without funeral gifts. Therefore menhirs at Bawah Parit Site, Mahat, Bukit Barisan District might part of cemeteries of certain ethnic groups. If that is the case, then some questions arise: Did plain and decorated menhirs, as well as their heights/lengths have any relation to the social status of the deceased? Is there any difference in the shape and location between menhirs that serve as tombstones or grave markers and those used as village markers? Therefore this area has to be further investigated.

\section{CONCLUSION}

The dating analysis and human skeleton reveal the culture and people lived in Lima Puluh Koto Megalithic area. There is a possibility that people who lived in the area for the first time were Austramelanisids. Later, Mongolids, came and mixed with modern humans who arrived in more recent period. They practiced Megalithic tradition. Based on that fact, it can be said that Lima Puluh Koto Megalithic was a tradition.

In relation to the diaspora of the Austronesian speakers, it is evidenced that they reached Sumatera Island, and settled there for a long period. They buried their deceased without burial container and used tombstones to mark the graves. The tombstones are decorated with floral vines resembling fern plants which is commonly found in the hills or shaped like sword's handle with the top part curved to one side. The menhirs are spread in groups. If put within the timeline of Austronesia in Indonesian Archipelago, the Megalithic tradition of Lima Puluh Koto belongs to Proto-historic Austronesia.

\section{SUGGESTIONS}

There are many other sites that have menhirs as their finds, which have not been investigated. Furthermore, more menhirs found when people working in the fields or forest, not to mention the ones used as foundations of traditional buildings. Therefore, reconstruction of distribution pattern is needed to know the modes of adaptation, with suitable natural environment and abundant raw material. Aside from menhirs, there are also stone mortars/troughs with the same vineshaped decorations like the ones found on the menhirs. The fact is supposed to answer why in Lima Puluh Koto area (West Sumatera) menhirs are the dominant finds while in South Sumatera (for instance in Pasemah) the most commonly finds are statues and dolmens, and in Lampung there are plenty of terraced structure and earth fortresses. In other places in Sumatera, particularly in highland areas like Kerinci Mountains, the finds include cylindrical stones and jar burials. Based on those facts, studying Austronesian culture in modern day context bring more data and information about the history of the ethnic groups in the Indonesian Archiplelago.

\section{Note:}

The author wish to thank Dr.Harry Widianto, who acted as a guide in this study. 


\section{BIBLIOGRAPHY}

Aziz, Fadhila Arifin, 1977 Batu Tegak (Menhir): Wujud Kreativitas Seni Hias Masyarakat Minangkabau Pada Masa Lampau. Bulletin Amoghapasa 7: 24-30. Balai Pelestarian Peninggalan Purbakala (BP3) Batusangkar, Sumatera Barat,

2010. "Potensi Situs Arkeologi Kawasan Kerinci, Jambi: Ikon Budaya Austronesia" dalam Amerta, vol. 28. ISSN 0125-1324 Jurnal Terakreditasi Penelitian dan Pengembangan Arkeologi hlm: 17-44. Jakarta: Pusat Penelitian dan Pengembangan Arkeologi Nasional. Badan Pengembangan Sumberdaya Kebudayaan dan Pariwisata, Kementerian Kebudayaan dan Pariwisata.

Bellwood, Peter. 1975. Man's Conquest of the Pacific, Auckland: Collins 1995. "Austronesian Prehistory in Southeast Asia: Homeland, Expansion and Transformation", dalam Peter Bellwood, James J.Fox, Darrell Tryon (eds), The Austronesians: Historical and Comparative Perspectives, Canberra: ANU, hlm. 96-111.

, 2000. Prasejarah Kepulauan Indo-Malaysia, Edisi Revisi, Jakarta: PT. Gramedia Pustaka Utama.

, 2011. "Holocene Population History in the Pacific Region as a Model for Worldwide Food Producer Dispersals". Current Anthropology Vol. 52, No. S4, The Origins of Agriculture: New Data, New Ideas, pp. S363-S378 The University of Chicago Press on behalf of Wenner-Gren Foundation for Anthropological Research DOI: 10.1086/658181 URL: http:// www.jstor.org/ stable/ 10.1086/658181, Page:16, diunduh 22 nov-2016, 2.21.

Blust, Robert. 1984. "Austronesian Culture History: Some Linguistic Inferences and their Relations to the Archaeological Record", dalan Peter Van de Velde, eds., Prehistoric Indonesia: A Rider. Dordrecht: Foris Publications, hlm. 218-241.

Bonatz,Dominik.1984-1985. "The Austronesian Homeland: A Linguistic Perspective", Asian Perspectives 26 (1), hlm. 45-68.

2009. "The Neolithic in The Highlands of Sumatera: Problrms of Definitions", From Distant Tales: Archaeology and Ethnohistory in the Highland of Sumatera, hlm. 43-74. Cambridge Scholars Publishing.

Creswell, John W. 1994. Research Design: Qualitative and Quantitative Approache, hlm 5. California: Sage Publication, Inc.

Fernandez, Inyo Yos. 2004. "Asal Mula Orang Austronesia", Polemik tentang Masyarakat Austronesia, Lembaga Ilmu Pengetahuan Indonesia 
bekerjasama dengan Direktorat Jenderal Pendidikan Tinggi, Departemen Pendidikan Nasional, hlm. 41-56.

Geldern, Robert von Heine. 1945. "Prehistoric Research in the Netherlands Indies", Science and Scientists in the Netherlands Indies, edited by Pieter Honig and Frans Verdoorn, New York Board for the Netherlands Indies.

Handini, Retno. 2005. Foraging yang Memudar, Suku Anak Dalam di Tengah Perubahan. Yogyakarta: Galang Press.

Hoop, A.N.J. Th a Th Van Der. 1938. "De Praehistorie", Geschiedenis Van Nederlandsch Indie, N.V. Uitgeversmaatschappij-Joost Van Den Vondel, Amsterdam.

Jacob, T. 1992. "Manusia Melayu Kuno", dalam Seminar Sejarah Melayu Kuno, Pemda Tingkat I Jambi bekerjasama dengan Kanwil Departemen Kebudayaan Propinsi Jambi, 7- 8 Desember, hlm. 152-157

Jacob, T. 1976. Ras, Etnis,dan Bangsa dalam Areologi Indonesia. Kumpulan Makalah IImiah Arkeologi IX. Kediri, 23-28 Juli 2001: 3 - 4. Jakarta: Ikatan Ahli Arkeologi Indonesia.

Kasnowihardjo, Gunadi H., 2012. "Temuan Manusia Austronesia di Pantura Jawa Tengah; Sebuah Kajian Awal”. Berkala Arkeologi Vol.33. Edisi No. 3. Yogyakarta: Balai Arkeologi, hlm 1-13.

Koentjaraningrat, 1982. Manusia dan Kebudayaan di Indonesia, Jakarta: Djambatan,

Masinambow, E.K.M. 2004. "Masyarakat Austronesia: Fakta atau Fiksi?", Polemik tentang Masyarakat Austronesia, Lembaga Ilmu Pengetahuan Indonesia bekerjasama dengan Direktorat Jenderal Pendidikan Tinggi, Departemen Pendidikan Nasional.

Simanjuntak, Truman, \& Hubert Forestier, 2004. "Research Progress on The Neolithique in Indonesia. Special reference to The Pondok Silabe Cave, South Sumatera", Southeast Asian Archaeology.Quezon city: University of The Philippines.

Simanjuntak, Truman. 2010. "Penutur dan Budaya Austronesia" dalam Arkeologi Indonesia dalam Lintasan Zaman. Jakarta: Pusat Penelitian dan Pengembangan Arkeologi Nasional, Badan Pengembangan Sumberdaya Kebudayaan dan Pariwisata, Kementerian Kebudayaan dan Pariwisata.

Simanjuntak, Truman. 2011. "Austronesia Prasejarah di Indonesia", Austronesia \& Melanesia di Nusantara, Penerbit Ombak, Yogyakarta. 
Simanjuntak, Truman. 2015. "Progres Penelitian Austronesia di Nusantara". Jurnal L Penelitian dan Pengembangan Arkeologi Amerta vol.33, No. 1, Juni, hl. 25-44. Pusat Arkeologi Nasional, Kementerian Pendidikan dan Kebudayaan.

Soejono, R. P. 2008. "Zaman Prasejarah Indonesia", Sejarah Nasional Indonesia I, Edited by Marwati Djoened \& Nugroho Notosusanto. Depantemen Pendidikan dan Kebudayaan. Jakarta: Balai Pustaka.

Sofian, Harry Octavianus. 2010. "Jejak-Jejak Budaya Penutur Austronesia Di Sumatera Selatan". Jurnal Papua Vol. 2. No.2/November. Balai Arkeologi Papua. Badan Pengembangan Sumberdaya Kebudayaan dan Pariwisata, Kementerian Kebudayaan dan Pariwisata, hlm. 103110.

Sukendar, Haris. 1985. "Penelitian Kepurbakalaan (ekskvasi) di situs Bawah Parit, Sumatera Barat", Laporan Penelitian , Jakarta: Pusat Penelitian Arkeologi Nasional (no published).

Sukendar, Haris. 1985. "Penelitian Kepurbakalaan (ekskvasi) di situs Bawah Parit, Sumatera Barat", Laporan Penelitian , Jakarta: Pusat Penelitian Arkeologi Nasional (no published).

Sukendar Haris, dkk. 1984. "Tradisi Megalitik di Kabupaten Lima Puluh Koto Provinsi Sumatera Barat", Laporan Penelitian , Jakarta: Pusat Penelitian Arkeologi Nasional (no published).

Tim Peneliti Tradisi, 1986, ,Penelitian Kepurbakalaan (Ekskavasi) di Situs Bawah Parit, Desa Koto Tinggi, Kecamatan Suliki Gunung Mas, Kabupaten Puluh Koto Sumatera Barat, Laporan Penelitian Arkeologi bidang prasejarah, Jakarta: Pusat Penelitian Arkeologi Arkeologi Nasional, (no Published).

Tanudirdjo, Daud A. dan Bagyo Prasetyo, 2004. "Model "Out of Taiwan dalam Perspektif Arkeologi Arkeologi Indonesia", dalam Polemik tentang Masyarakat Asutronesia: Fakta atau Fiksi? Prosiding Kongres IImu Pengetahuan VIII, Lembaga IImu Pengetahuan Indonesia bekerja sama dengan Direktorat Jendral Pendidikan Tinggi Departemen Pendidikan Nasional, hlm. 77-101.

Tim Peneliti Tradisi Megalitik Sumatera Barat, 1984. "Penelitian Tradisi Megalitik di Kabupaten Lima Puluh koto Sumatera Barat." Laporan Penelitian Arkeologi bidang prasejarah, Pusat Penelitian Arkeologi Nasional, (no published).

Triwurjani, Rr., 2011. Situs-Situs Megalitik di DAS Sekampung. Jakarta: Wedatama Widya Sastra. 
Triwurjani, Rr, dkk., 2012. "Sebaran Menhir di Kawasan Lima Puluh Koto " dalam Tradisi Megalitik di Lima Puluh Koto. Jakarta: Wedatama Widya Sastra, hlm. 29-57

Triwurjani, Rr, dkk., 2012. "Pusat Budaya Megalitik Kawasan Lima Puluh Koto" dalam Tradisi Megalitik di Lima Puluh Koto. Jakarta: Wedatama Widya Sastra, hlm. 1-28

Triwurjani, 2012. "Ragam Hias 'Keluak Paku' pada Menhir-menhir di Kabupaten Lima Puluh Koto, Sumatera Barat. Arkeologi Untuk Publik Proceedings Pertemuan Ilmiah Arekologi, Jakarta: Ikatan Ahli Arkeologi Indonesia (IAAI), Jakarta: Wedatama Widya Satra, hlm. 808-824.

Triwurjani, Rr., Harry Widianto, Ni Komang Ayu Astiti, Arfian. 2009. "Laporan Penelitian Pusat Budaya Megalitik Kawasan Lima Puluh Koto, Sumatera Barat, Kajian Budaya dan Manusia", Riset Terapan Puslitbang Arkeologi Nasional, Jakarta: Badan Pengembangan Sumber Daya Budaya, Departemen Kebudayaan dan Pariwisata.

Triwurjani, Rr., Arfian, Sudarti, Nurul Laily, Efriyanto. 2010. “Laporan Penelitian Pengembangan Sistem Informasi Database Sistem Infromasi Arkeologi dalam Pola Sebaran Sumberdaya Arkeologi Kawasan Megalitik Lima Puluh Koto, Sumatera Barat". Riset Terapan Puslitbang Arkeologi Nasional, Jakarta: Badan Pengembangan Sumber Daya Budaya, Departemen Kebudayaan dan Pariwisata dan Kementerian Riset dan Teknologi. Kebudayaan dan Pariwisata dan Kementerian Riset dan Teknologi.

Vita, et.al., 2005. "Laporan Penelitian Arkeologi Bidang Arkeometri Situs Guguk Nunang Kawasan Megalitik Lima Puluh Koto". Jakarta: Pusat Penelitian Arkeologi Nasional, (no published).

Widianto, Harry. 2008. The Dawn of Humanity in Sumatera: Arrival and Dispersal From The Human Remain Perspective (in pressed).

Yuwono Sudibyo, 1984. "Menhir di Kawasan Lima Puluh Koto: Sebuah Pengamatan Dalam Kebudayaan", Jakarta: Departemen Pendidikan Nasional. 